\title{
MODEL PEMBELAJARAN KOPERATIF TIPE JIGSAW DALAM HASIL BELAJAR IPA SISWA KELAS IX-4 SMP NEGERI 1 BANGUN PURBA
}

\author{
Erhaini Purba \\ Guru IPA SMP Negeri 1 Bangun Purba \\ Surel : rizkiandriani21@yahoo.com
}

\begin{abstract}
Abstrak
Penelitian ini bertujuan untuk meningkatkan hasil belajar siswa melalui penerapan model pembelajaran kooperatif tipe Jigsaw. Awal KBM dilakukan tes hasil belajar (Pretes), dengan data rata-rata 41. Kemudian dilanjutkan KBM, akhir KBM ke II dan KBM ke IV dilakukan tes hasil belajar formatif I dan Formatif II hasilnya masing-masing menunjukkan rata-rata 57,8 dan 86,8. Melihat data tersebut ada perubahan dan perubahan tersebut akibat tindakan guru selama KBM pada siklus II. Data aktivitas siswa menurut pengamatan pengamat pada siklus I antara lain membaca/menulis (40\%), bekerja (28\%), bertanya sesama teman (12\%), bertanya kepada guru pada siklus II antara lain membaca/menulis (26\%), bekerja (45\%), bertanya sesame teman (16\%), bertanya kepada guru (12\%) dan dan yang tidak relevan dengan KBM (2\%). Penerapan model pembelajaran Jigsaw dari siklus I ke siklus II mengalami peningkatan.
\end{abstract}

Kata Kunci : Model Kooperatif, Jigsaw, Hasil belajar

PENDAHULUAN

Untuk mencerdaskan kehidupan manusia, maka pendidikan menjadi salah satu sarana utama yang perluh di usahakan dan dikelola sebaik mungkin sejalan perkembangan masa maupun perkembangan hidup manusia. Pendidikan adalah upaya untuk mengembangkan kemampuan dan memotivasi manusia sehingga dapat hidup lebih baik lagi, baik sebagai individu maupun maupun sebagai anggota masyarakat. Pendidikan bertujuan untuk mendewasakan anak, kedewasaan tersebut mencangkup kedewasaan intelektual, sosial, dan moral, tidak semata-mata kedewasaan fisik. Pendidikan tidak hanya bertumpu pada pendidikan formal tetapi di dapat dari pendidikan nonformal.

Setiap manusia membutuhkan pendidikan karena melalui pendidikan manusia dibekali dengan pengetahuan, kepribadian, dan keterampilan sehingga ia mampu berusaha dan bekerja untuk meraih kehidupan yang dicita-citakan tersebut, namun hal itu kembali pada individu manusia itu sendiri.

Dunia pendidikan tidak terlepas dari proses belajar kerena tujuan pendidikan diatas dapat dicapai melalui proses belajar di suatu lembaga pendidikan yaitu sekolah. Sekolah merupakan lembaga untuk menempah sumber daya manusia yang berkualitas. Namun dalam mencapainya sumber 
manusia berkualitas ditunjukan melalui pembelajaran di sekolah.

Dalam usaha meningkatkan sumber daya manusia, pendidikan guru merupakan komponen sumber daya manusia yang harus dibina dan dikembangkan terus menerus. Hal ini berarti bahwa guru dituntut menguasai bidang studi yang diajarkan dan kemudian mengajarkan kepada siswa agar dapat efektif dan efisien. Untuk mencapai tujuan pembelajaran di sekolah, perlu adany adukungan dari faktor-faktor yang saling terkait antara lain faktor guru, siswa, kurikulum, sarana dan prasarana, lingkungan dan kondisi sosial.

Keberhasilan

suatu

pembelajaran dapat dipengaruhi oleh model pembelajaran yang digunakan guru. Jika model pembelajarannya menarik dan terpusat pada siswa (student-centered learning) maka motivasi dan perhatian siswa akan meningkat dan selanjutnya kualitas pembelajaran juga dapat meningkat.

Pada kenyataannya saat ini masih banyak guru yang masih menggunakan model pembelajaran konvensional yang berpusat pada guru (teacher oriented), dimana dalam proses belajar mengajar guru lebih sering menggunakan metode mengajar yang monoton, yaitu dengan metode ceramah, dan tanya jawab. Hal ini tentu akan menimbulkan kejenuhan bagi siswa dalam kegiatan belajar mengajar

Oleh karena itu sudah selayaknya dalam kegiatan belajar mengajar, guru memvariasikan cara mengajarnya dengan model pembelajaran kooperatif. Model pembelajaran kooperatif digunakan untuk mempengaruhi perhatian siswa, agar sepenuhnya tertuju dalam kegiatan belajar-mengajar sehingga dapat meningkatkan hasil belajar.

Dalam pelaksanaan pembelajaran IPA di SMP Negeri 1 Bangun Purba, hasil belajar anak rendah hal ini disebabkan saya sebagai guru masih mendominasi kegiatan belajar mengajar sehingga siswa cenderung diam ketika belajar. Dan hasil nilai ulangan harian pertama nilai siswa cenderung di bawah KKM.

Kemudian siswa menganggap materi pada mata pelajaran IPA susah. Seperti materi kemagnetan, siswa menganggap materi sangat susah. Saya menyadari sebagai guru perluh melakukan pemaham yang jelas kepada siswa karena materi kemagnetan sangat perluh dan digunakan dalam kehidupan seharihari. Oleh karena itu dalam pelajaran IPA terutama materi kemagnetan guru harus dapat melibatkan langsung dalam pembelajaran dan perluh merangcang atau membuat kegiatan pembelajaran siswa mudah memahami materi yang dipelajari.

Untuk memahami materi tersebut diperluhkan model pembelajaran yang dapat memudahkan siswa untuk memahami materi dan meningkat hasil belajar siswa yaitu dengan saya mencoba untuk menggunakan model pembelajaran Kooperatif tipe Jigsaw, karena model pembelajaran Jigsaw 
merupakan suatu Model pembelajaran yang interaktif dan dinamis sehingga dapat dijadikan dalam memilih model pembelajaran.

Dalam hal ini model pembelajaran Jigsaw sangat berperan untuk menerapkan konsep-konsep yang ada dalam pembelajaran, sehingga dapat diikuti dan dipelajari siswa dengan lebih rileks dan santai tanpa dibayangi dengan ketakutan dan kesulitan dalam mempelajari pelajaran IPA Terpadu. Siswa juga dapat melakukan pembelajaran dengan bekerja sama secara berkelompok dan keberhasilan belajar bukan hanya dari guru atau individu saja akan tetapi keberhailan belajar juga didapat dari orang-orang yang terlibat dalam pembelajaran dan juga meningkatkan hasil belajar serta memudahkan siswa dalam memahami materi pelajaran khususnya pelajaran IPA.

Berdasarkan latar belakang diatas yang telah diuraikan, dapat di indentifikasi masalah, yaitu : (1) Proses pembelajaran dilaksanakan secara monoton karena cenderung kurang menerapkan model pembelajaran yang variatif dan menarik, (2) Rendahnya kreatifitas belajar siswa sehingga berdampak pada hasil dan aktivitas belajar siswa untuk pelajaran IPA masih rendah. Selanjutnya, dari indentifikasi didapat rumusan masalah, yaitu : (1) Apakah hasil belajar siswa meningkat setelah menerapkan model Pembelajaran Jigsaw di kelas IX- 4 SMPN 1 Bangun Purba?, (2) Apakah aktivitas belajar siswa mengalami peningkatan melalui penerapan model pembelajaran Jigsaw di kelas IX-4 SMPN 1 Bangun Purba?

Adapun tujuan penelitian ini, antara lain: (1) Untuk mengetahui hasil belajar siswa setelah menerapkan model Pembelajaran Jigsaw di kelas IX-4 SMPN 1 Bangun Purba. (2) Untuk mengetahui aktivitas siswa setelah diterapkannya model pembelajaran Jigsaw di kelas IX-4 SMPN 1 Bangun Purba.

Menurut Slameto (2003:2) menyatakan bahwa "Belajar adalah suatu proses usaha yang dilakukan seseorang untuk memperoleh suatu perubahan tingkah laku yang baru secara keseluruhan sebagai hasil dari pengalaman sendiri dan interaksinya dengan lingkungannya". Selain itu Winkel (2005:6) menyatakan bahwa "belajar adalah suatu aktifitas mental/psikis yang berlangsung dalam interaksi aktif dengan lingkungan yang menghasilkan perubahan - perubahan pengetahuan, pemahaman, keterampilan, dan sikap". Sedangkan menurut Mc Mahon berdasarkan teori kontruktivisme 'Belajar' bukanlah semata-mata mentransfer pengetahuan yang ada di luar dirinya, tetapi belajar lebih bagaimana otak memproses dan menginterpretasikan pengalaman yang baru dengan pengetahuan yang sudah dimilikinya dalam format yang baru. Proses pembangunan ini bisa melalui asimilasi atau akomodasi.

Proses belajar dan hasil belajar merupakan hal yang penting 
dalam belajar biologi, dimana proses dan hasil belajar berkaitan erat satu sama lain. Dari pengertian belajar, telah dijelaskan bahwa belajar merupakan proses perubahan dan perubahan baru merupakan hasil belajar. Seperti pernyataan yang diungkapkan oleh Djamarah (2002:14) tentang hubungan proses dan hasil belajar, yakni : untuk mendapatkan hasil belajar dalam bentuk 'perubahan' harus melalui proses tertentu yang dipengaruhi oleh faktor dari dalam diri individu dan dari luar diri individu. Proses disini tidak dapat dilihat karena bersifat psikologis. Kecuali bila seseorang berhasil dalam belajar, maka seseorang itu telah mengalami proses tertentu dalam belajar. Oleh karena itu, proses belajar telah terjadi dalam diri seseorang hanya dapat disimpulkan dari hasilnya, karena aktivitas belajar yang dilakukan.

Sementara itu, Keller memandang hasil belajar sebagai hasil keluaran dari suatu sistem pemrosesan berbagai masukan yang berupa informasi. Berbagai masukan tersebut dikelompokkan menjadi dua macam yaitu: (1) Kelompok masukan pribadi, terdiri dari motivasi; harapan untuk berhasil; intelegensi dan penguasaan awal; dan evaluasi kognitif. (2) Kelompok masukan yang berasal dari lingkungan, terdiri dari rancangan dan pengelolaan motivasional; rancangan dan pengelolaan kegiatan belajar; dan rancangan dan pengelolaan ulangan penguatan (Abdurrahman, 2003:38).
Aktivitas belajar adalah suatu aktivitas yang sadar akan tujuan. Tujuan dalam belajar adalah terjadinya perubahan dalam individu seutuhnya. Menurut Djamarah (2002:38), ada beberapa aktivitas belajar yaitu mendengarkan, memandang, menulis atau mencatat, membaca, membuat ikhtisar atau ringkasan dan menggaris bawahi. Mengamati tabel-tabel, diagramdiagram dan bagan-bagan, menyusun paper atau kertas kerja, mengingat, berpikir, dan latihan atau praktek

$$
\text { Jigsaw adalah tipe }
$$

pembelajaran kooperatif untuk mendorong siswa saling membantu dan termotivasi menguasai ketrampilan yang diberikan oleh guru. Dalam model pembelajaran tipe Jigsaw, setiap anggota kelompok bertanggung jawab atas penugasan bagian dari materi belajar yang ditugaskan kepadanya lalu mengajarkan bagian tersebut kepada anggota kelompoknya yang lain.

Jigsaw telah dikembangkan dan diuji coba oleh Elliot Aronson dan teman-teman dari Universitas Texas dan kemudian diadaptasi oleh Salvin di Universitas John Hopkins (Trianto, 2011:75). Dalam penerapkan Jigsaw, siswa dibagi kelompok dengan 4 atau 6 anggota kelompok belajar heterogen. Setiap anggota bertanggung jawab untuk mempelajari bagian tertentu bahan yang diberikan itu. Anggota dari kelompok yang berbeda dari topik yang sama bergabung membentuk sebuah kelompok (kelompok ahli) untuk berdiskusi dan saling 
membentuk satu sama lain tentang topik pembelajaran yang ditugaskan kepada mereka. Kemudian siswasiswa itu kembali kepada kelompoknya masing-masing (kelompok asal) untuk menjelaskan kepada kelompok anggotanya yang lain tentang apa yang telah mereka pelajari sebelumnya.

\section{METODOLOGI PENELITIAN}

Lokasi penelitian ini dilakukan di SMPN 1 Bangun Purba. Materi Pembelajaran yang diterapkan selama pengambilan data di kelas IX-4 SMPN 1 Bangun Purba adalah memahami Kemagnetan. Menurut silabus materi tersebut delapan jam pelajaran merujuk pada silabus maka ada 4 RPP yang diterapkan selama pengambilan data di sekolah. Penelitian ini direncanakan mulai bulan Februari sampai dengan Juli Tahun 2015.

Subjek dalam penelitian ini yaitu kelas IX-4 SMP Negeri 1 Bangu Purba dengan jumlah 38 orang siswa.

\section{Rencana Penelitian}

Adapun kegiatan yang dilakukan dalam tahap perencanaan ini adalah : (1) analisis kurikulum, (2) membuat skenario pembelajaran, (3) membuat tes Hasil Belajar, (4) menyusun tugas yang akan dikerjakan tiap siswa (LKS), (5) membuat lembar observasi untuk melihat bagaimana kondisi belajar mengajar langsung dalam kelas.
Menurut Raka Joni (dalam Sudibio E. 2003: 8-9), terdapat 6 (enam) tahap dalam pelaksanaan penelitian tindakan kelas (PTK). Ke enam tahap dalam pelaksanaan tersebut antara lain :

a. Permasalahan. Merumuskan masalah-masalah apa yang dapat diselesaikan selama penelitian ini antara lain : (1) Analisis Kurikulum, Instrumen Tes hasil belajar : Instrumen Tes hasil belajar ini terdiri dari soal sesuai dengan jumlah indikator pada RPP, (3) Rencana Pelaksanaan Pembelajaran, (4) Lembar Kerja Siswa (LKS), (5) Lembar Ativitas belajar Siswa, (6) Lembar obeservasi tentang sikap selama siswa belajar dalam kelompok, (7) Model Pembelajaran yang sesuai dengan karakteristik siswa.

b. Alternatif Pemecahan masalah. Setelah selesai dianalisis sesuai dengan kebutuhan selama penelitian, maka Instrumeninstrumen diselesaikan, sehingga dapat merekam data selama pengambilan data di sekolah.

c. Pelaksanaan Tindakan Perbaikan. Prosedur Penelitian Tindakan Kelas ini terdiri dari dua siklus yaitu siklus I dan Siklus II. Masing-masing siklus menerapkan dua kali kegiatan belajar mengajar, sesuai dengan perubahan yang dicapai, seperti apa yang telah direncanakan dalam faktor yang diselidiki, 
untuk dapat melihat perubahan kemampuan siswa dalam menyerap materi pembelajaran.

d. Observasi. Pada tahap ini observasi dilakukan saat bersamaan dengan tahap pelaksanaan tindakan selama pengambilan data oleh peneliti/pengamat. Pada tahap observasi ini, pengamat menggunakan lembar pedoman aktivitas dan lembar observasi. Pada tahap pelaksanaan tindakan ada 2 orang pengamat (guru) menggunakan Instrumen aktivitas belajar siswa, mengamati aktivitas siswa selama bekerja dalam kelompok. Pengambilan data dilakukan 2 menit sekali oleh pengamat yang ada di dalam kelas. Sampel yang diamati 1 kelompok per pengamat dan kelompok yang diamati ditentukan oleh peneliti sendiri tanpa sepengetahuan kelompok siswa. Sehingga selama 1 kegiatan belajar mengajar ada 2 kelompok yang diamati. Selama pengambilan data ada 4 kali pertemuan berarti ada 8 kelompok yang teramati oleh kedua pengamat, kemudian data-data dari ke dua pengamatan akhir KBM diserahkan kepeneliti.

e. Analisis Data. Setelah data terkumpul mengenai data hasil belajar siswa, aktivitas belajar, dan hasil observasi selama kegiatan belajar mengajar, maka data tersebut dianalisis, sehingga dapat diketahui karakter siswa tentang pemahaman materi pembelajar, dan sikap siswa selama bekerja perindividu atau berkelompok.

f. Refleks. Tahap ini dilakukan untuk menganalisa dan memberi arti terhadap data yang diperoleh memperjelas data yang diperoleh sehingga diambil kesimpulan dari tindakan yang telah dilakukan.

\section{Prosedur Penelitian}

Secara ringkas skenario kegiatan belajar mengajar disajikan sebagai berikut (Gambar 3.1) Pertemuan Pertama dilakukan pre tes (ujian awal) untuk melihat kemampuan awal siswa sebagai bahan masukan bagi peneliti/guru. Pertemuan berikutnya dilakukan KBM dua kali disebut Siklus I dan diakhiri dengan formatif I. Kegiatan belajar dilanjutkan hari berikutnya selama dua kali (Siklus II) dan akhir pembelajaran dilakukan formatif II.

\section{Instrumen Penelitian}

Instrumen selama penelitian antara lain:

a. Instrumen Tes hasil Belajar

b. Instrumen aktivitas belajar siswa

\section{Teknik Analisis Data}

Data-data yang terkumpul selama penelitian ini adalah:
a. Data Pre tes siswa
b. Data formatif pertama
c. Data formatif ke dua
d. Data aktivitas siswa 
Untuk menganalisis data-data tersebut di atas digunakan:

a. Teknik persentase, untuk menganalisis tingkat keberhasilan tes hasil belajar.

b. Teknik deskriptif, untuk menganalisis data-data presentase.

\section{HASIL PENELITIAN DAN PEMBAHASAN}

Sebelum melaksanakan siklus I maka terlebih dahulu peneliti mengumpulkan data untuk melihat kondisi siswa sebelum dilakukan penelitian. Adapun pengumpulan data yakni dengan memberikan uji pretes kepada siswa. Data yang diperoleh yakni tidak seorangpun siswa mendapat nilai di atas KKM 75 , dengan ketuntasan klasikal $0 \%$ dan rata-rata nilai 41. Hal ini menunjukkan bahwa siswa tidak pernah mempersiapkan diri sebelum mengikuti pembelajaran dan rendahnya aktivitas belajar siswa di rumah.

\section{Siklus I}

Pada siklus I didapat hasil cukup memuaskan dengan nilai ratarata kelas 65. Akhir Siklus I dilakukan tes hasil belajar atau disebut Formatif I, dengan data dapat dilihat Pada Tabel 1. Merujuk pada kesimpulan ini guru sebagai peneliti berusaha memperbaiki proses dan hasil belajar siswa Melalui Model Pembelajaran Kooperatif Tipe Jig Saw. Hasil belajar yang diperoleh pada siklus I selama dua pertemuan disajikan dalam Tabel berikut :

Tabel 1. Distribusi Hasil Formatif I

\begin{tabular}{|c|c|c|c|c|}
\hline Nilai & Frekuensi & $\begin{array}{c}\text { Tuntas } \\
\text { Individu }\end{array}$ & $\begin{array}{c}\text { Tuntas } \\
\text { Kelas }\end{array}$ & $\begin{array}{c}\text { Nilai } \\
\text { Rata- } \\
\text { rata }\end{array}$ \\
\hline 50 & 16 & - & - & \multirow{2}{*}{} \\
\cline { 1 - 4 } 75 & 21 & 21 & $55,2 \%$ & \multirow{2}{*}{65} \\
\cline { 1 - 4 } 100 & 1 & 1 & $2,6 \%$ & \\
\hline Jumlah & 38 & 22 & $57,8 \%$ & \\
\hline
\end{tabular}

Pada Tabel 1 tersebut, nilai terendah formatif I adalah 50 sebanyak 16 orang dan nilai tertinggi adalah 100 sebanyak 1 orang, dengan 22 orang mendapat nilai di atas kriteria ketuntasan atau ketuntasan klasikal adalah sebesar 57,8\%. Dengan nilai KMM sebesar 75 nilai ini berada sedikit di bawah kriteria keberhasilan klasikal sehingga dapat dikatakan KBM siklus I kurang berhasil memberi ketuntasan belajar dalam kelas. Nilai rata-rata kelas adalah 65 belum tuntas KKM.

Kemudian dilihat aktivitas belajar, Skor Aktivitas Belajar diperoleh dari lembar observasi aktivitas. Pengamatan dilakukan oleh dua pengamat selama 20 menit kerja kelompok dalam setiap KBM atau 40 menit dalam satu siklus. Dengan pengamatan setiap 2 menit, maka nilai maksimum yang mungkin teramati untuk satu kategori aktivitas selama 40 menit adalah 20 kali. Adapun data aktivitas yang diperoleh selama 40 menit pada siklus I adalah sebagai berikut: 
Tabel 2 Skor Aktivitas Belajar Siswa

\begin{tabular}{|c|l|c|c|c|}
\hline \multicolumn{5}{|c|}{ Siklus I } \\
\hline No & \multicolumn{1}{|c|}{ Aktivitas } & Jumlah & $\begin{array}{c}\text { Rata- } \\
\text { Rata }\end{array}$ & Persentase \\
\hline 1 & $\begin{array}{l}\text { Menulis, } \\
\text { Membaca }\end{array}$ & 72 & 18 & $40 \%$ \\
\hline 2 & Mengerjakan & 50 & 12,5 & $28 \%$ \\
\hline 3 & $\begin{array}{l}\text { Bertanya pada } \\
\text { teman }\end{array}$ & 22 & 5,5 & $12 \%$ \\
\hline 4 & $\begin{array}{l}\text { Bertanya pada } \\
\text { guru }\end{array}$ & 16 & 4 & $9 \%$ \\
\hline 5 & $\begin{array}{l}\text { Yang tidak } \\
\text { relevan }\end{array}$ & 20 & 5 & $11 \%$ \\
\hline & Jumlah & 180 & 40 & $100 \%$ \\
\hline
\end{tabular}

\section{Siklus II}

Data-data Formatif I dianalisis, sehingga mendapat suatu gambaran tentang keberhasilan siswa. Untuk memperbaiki hasil belajar siswa, peneliti memberikan suatu gambaran hasil belajar siswa pada Formatif I sesama peneliti/guru kemudian didiskusikan untuk mengambil tindakan berikutnya pada Siklus II. Diskusi tersebut juga dilakukan terhadap pembimbing PTK agar pada tindakan berikutnya aktivitas siswa semakin baik dan hasil belajarnya juga lebih baik.

Uraian di atas menyatakan bahwa pada Siklus I indikator keberhasilan belum tercapai karena terdapat 16 siswa yang belum tuntas nilainya. Oleh karena itu perlu adanya suatu tindakan pada Siklus II agar hasil belajar siswa dapat ditingkatkan dan mencapai indikator keberhasilan dengan ketuntasan klasikal mencapai maksimum. Akhir KBM ke empat dilakukan tes hasil belajar atau disebut Formatif II, datanya dapat dilihat Pada Tabel 3.

Tabel 3. Distribusi Hasil Formatif II

\begin{tabular}{|c|c|c|c|c|}
\hline Nilai & Frekuensi & $\begin{array}{c}\text { Tuntas } \\
\text { Individu }\end{array}$ & $\begin{array}{c}\text { Tuntas } \\
\text { Kelas }\end{array}$ & $\begin{array}{c}\text { Rata- } \\
\text { rata }\end{array}$ \\
\cline { 1 - 4 } 67 & 5 & - & - & \\
\cline { 1 - 4 } 83 & 21 & 21 & $55,2 \%$ & \multirow{2}{*}{86,4} \\
\cline { 1 - 4 } 100 & 12 & 12 & $31,6 \%$ & \\
\cline { 1 - 4 } Jumlah & 38 & 33 & $86,8 \%$ & \\
\hline
\end{tabular}

Merujuk pada Tabel 3, nilai terendah untuk Formatif II adalah 67 sebanyak 4 orang dan tertinggi adalah 100 sebanyak 12 orang. Dengan 5 orang mendapat nilai dibawah kriteria ketuntasan atau ketuntasan klasikal adalah sebesar $86,8 \%$. Nilai rata-rata kelas adalah 86,4 .

Kemudian, Data aktivitas siswa selama kegiatan belajar mengajar dapat dilihat pada tabel di bawah ini :

Tabel 4. Skor Aktivitas Belajar Siswa

\begin{tabular}{|c|l|c|c|c|}
\hline \multicolumn{5}{|c|}{ Siklus II } \\
\hline No & \multicolumn{1}{|c|}{ Aktivitas } & Jumlah & $\begin{array}{c}\text { Rata- } \\
\text { Rata }\end{array}$ & Persentase \\
\hline 1 & $\begin{array}{l}\text { Menulis, } \\
\text { Membaca }\end{array}$ & 51 & 12,75 & $26 \%$ \\
\hline 2 & Mengerjakan & 90 & 22,5 & $45 \%$ \\
\hline 3 & $\begin{array}{l}\text { Bertanya pada } \\
\text { Teman }\end{array}$ & 32 & 8 & $16 \%$ \\
\hline 4 & $\begin{array}{l}\text { Bertanya pada } \\
\text { Guru }\end{array}$ & 23 & 5,75 & $12 \%$ \\
\hline 5 & $\begin{array}{l}\text { Yang tidak } \\
\text { Relevan }\end{array}$ & 4 & 1 & $2 \%$ \\
\hline \multicolumn{2}{|c|}{ Jumlah } & 200 & 50 & $100 \%$ \\
\hline
\end{tabular}


Dari data hasil penelitian yang telah tersaji pada tabel 1, 2, 3 dan 4. Dari data tabel 1 dan 3 terjadi mengalami peningkatan yang sangat signifikan pada hasil belajar siswa, dari semula hanya 22 siswa atau sebesar 57,8\% yang tuntas belajar pada siklus I meningkat menjadi 33 siswa atau sebesar $86,8 \%$ pada akhir siklus II, yang berarti mengalami peningkatan. Sementara itu untuk kategori penilaian hasil yang lain, yakni kategori siswa yang tidak tuntas, dari semula sebanyak 16 siswa $(42,1 \%)$ yang tidak tuntas pada siklus I berkurang secara drastis menjadi hanya 5 siswa $(13,1 \%)$ yang tidak tuntas pada akhir siklus II, yang berarti berkurang sebesar $29 \%$.

\section{Pembahasan}

Memang harus diakui, bahwa dengan model pembelajaran kooperatif seperti yang diterapkan siswa sepertinya merasakan adanya suasana belajar yang menyenangkan (joyful learning atau learning is fun). Hal ini setidaknya terbukti dari data hasil belajar atau prestasi belajar siswa sebagaimana tersajikan pada tabel 1 dan Tabel 2 di atas dengan jelas membuktikan bahwa telah terjadi Bila dilihat dari segi kriteria keberhasilan secara klasikal yang telah ditetapkan, yakni sebesar $85 \%$ dari seluruh siswa dalam kelas harus mencapai ketuntasan belajar, sementara dari penilaian hasil di akhir siklus II ini hanya menyisakan $14,2 \%$ yang tidak tuntas (yang berarti $86,8 \%$ siswa telah mencapai ketuntasan belajar), maka dari situ dapat dipahami lebih jauh bahwa tindakan guru melalui penerapan pembelajaran kooperatif tipe Jigsaw ini telah berhasil mencapai tujuannya.

Kemudian dari pada tabel 2, dan table 4 aktivitas belajar siswa. pada siklus I aktivitas belajar siswa sebagai berikut: aktivitas menulis dan membaca 40\%, aktivitas mengerjakan LKS 28\%, aktivitas bertanya pada teman $12 \%$, aktivitas bertanya pada guru 9\%, aktivitas yang tidak relevan dengan KBM $11 \%$. Pada siklus II, aktivitas menulis dan membaca turun menjadi $26 \%$ yang mengindikasikan siswa sudah mempersiapkan diri dari rumah sehingga siswa tidak lagi perlu banyak membaca di sekolah pada saat pelaksanaan diskusi, hal ini juga mengindikasikan turunnya tindakan individual siswa. Aktivitas mengerjakan LKS pada siklus II mengalami peningkatan yang cukup pesat yakni dari $28 \%$ menjadi $45 \%$. Hal ini menunjukkan bahwa siswa menjadi lebih aktif dalam mengerjakan LKS. Aktivitas bertanya kepada teman mengalami peningkatan menjadi $16 \%$, hal ini menunjukkan siswa menjadi lebih kooperatif dan lebih bekerjasama dengan temannya, sehingga aktivitas bertanya meningkat. Aktivitas bertanya pada guru mengalami kenaikan menjadi $12 \%$ hal ini mengindikasikan siswa sudah masih belum bisa untuk mandiri dalam berpikir sehingga membutuhkan guru. Aktivitas yang tidak relevan juga menyusut dari $11 \%$ menjadi 2 
\%. Seluruh data aktivitas di atas menunjukkan bahwa aktivitas belajar siswa menjadi lebih baik dari siklus I ke siklus II.

Jigsaw didesain untuk meningkatkan rasa tanggung jawab siswa terhadap pembelajarannya sendiri dan juga pembelajaran orang lain. Siswa tidak hanya mempelajari materi yang diberikan, tetapi mereka juga harus siap memberikan dan mengajarkan materi tersebut pada anggota kelompoknya yang lain. Dengan demikian, "siswa saling tergantung satu dengan yang lain dan harus bekerja sama secara kooperatif untuk mempelajari materi yang ditugaskan".

\section{SIMPULAN DAN SARAN}

Data-data tes hasil belajar, aktivitas belajar siswa, dan minat siswa terhadap model pembelajaran kooperatif Tipe Jigsaw selama kegiatan belajar mengajar, kemudian dianalisis, sehingga dapat disimpulkan sesuai dengan rumusan masalah.

a. Dengan menerapkan model pembelajaran kooperatif Tipe Jig Saw hasil siswa dari Siklus ke Siklus berikutnya mengalami peningkatan. Hasil belajar siswa pada Formatif I dan Formatif II menunjukkan 22 orang siswa tuntas secara individu, sedangkan kelas tidak tuntas. Pada Siklus II, tuntas secara individu sebanyak 33 orang siswa, sedangkan kelas adalah tuntas dengan rata-rata siklus I dan siklus II adalah 65 dan 86,4. Dengan rata-rata klasikal siklus $157,8 \%$ dan siklus II $86,8 \%$.

b. Data aktivitas siswa menurut kedua pengamatan pengamat pada Siklus I antara lain: menulis/membaca (40\%), bekerja (28\%), bertanya sesama teman $(12 \%)$, bertanya kepada guru (9\%), dan yang tidak relevan dengan KBM (11\%). Dan Data aktivitas siswa menurut pengamatan pada Siklus II antara lain: menulis/membaca (26\%), bekerja $(45 \%)$, bertanya sesama teman $(16 \%)$, bertanya kepada guru (12\%), dan yang tidak relevan dengan $\mathrm{KBM}(2 \%)$.

\section{DAFTAR RUJUKAN}

Aqib, Zainal. 2006. Penelitian Tindakan Kelas. Bandung: Yrama Widya.

Arikunto, S. 1999. Prosedur Penelitian Suatu Strategi Praktek, Jakarta: Rineka Cipta.

Gagne, R. M. 1993. Some Issues in the Psychology of Mathematics Instruction, Journal for Research in Mathematics Education.

Hamalik, Oemar. 2009. Kurikulum dan Pembelajaran. Jakarta: Penerbit Bumi Aksara.

Hudoyo, H. 1990. Strategi Belajar Mengajar Bahasa inggris. Malang: IKIP Malang.

Komarudin, Ukim dan M. Sukardjo. 2009. Landasan Pendidikan Konsep dan Aplikasinya. 
Jakarta: Penerbit Rajawali Pers.

Muslich, Masnur. 2009. KTSP Dasar

Pemahaman dan

Pengembangan. Jakarta:

Penerbit Bumi Aksara.

Trianto. 2011. Mendesain Model Pembelajaran
Progresif. Jakarta: Penerbit Kencana.

Slameto. 2010. Belajar dan FaktorFaktor yang Mempengaruhinya. Jakarta: Penerbit Rineka Cipta Siagian, dkk. 2010. Learning English 2. Jakarta: Penerbit Kencana. 